\title{
OPTIMAL SIZE OF THE GENERAL GOVERNMENT SECTOR FROM THE POINT OF VIEW OF ITS IMPACT ON THE EU ECONOMIES
}

Teresa Mroczek, Tomasz Skica, Jacek Rodzinka

\section{Abstract}

This article is an attempt to determine the optimal size of the general government sector (GGS) from the point of view of the economies of EU countries. Achievement of this research objective implied a few intermediate objectives. Firstly, measures enabling the description of the size of the general government sector were identified. In order to do that, measures present in the literature, classical measures of size of the GGS, as well as the public sector were extended to include additional measures proposed by the authors. Selected variables enabled us to measure the size of the GGS, choosing sector variables which positively influenced the economies of EU countries. Based on that, researches on optimization of the size of the general government sector from a perspective of the economies of EU countries were made, using for that purpose an approach based on diagnostic inference. A combination of research methodology innovative for such elaborations on the topic adopted by the authors resulted in the paper, presenting in a complex manner the issues of combining measures and impact of the general government sector on the economies of the researched countries.

JEL Classification: $\mathrm{E} 62, \mathrm{H} 11, \mathrm{H} 2 \mathrm{O}, \mathrm{H} 5 \mathrm{O}, \mathrm{H} 60$,

Keywords: General government sector (GGS), economy, diagnostic inference, public finance

\section{INTRODUCTION}

The main purpose of this paper is to indicate the optimum size of the general government sector (GGS) in the European Union (EU) economies. The goal of the study is especially important due to the fact that the problems with the optimal size of the GGS in the scientific literature have not been fully solved and discussed in detail. On the one hand, it has attracted the attention of a variety of approaches to determine the general government sector's size (see: Skica et al. 2015a, Skica et al. 2015b), and on the other hand - a kind of monogamy of methods for the determination of its optimal dimensions. The approaches present in research studies (both a little older, and quite modern), to the optimization of the size of the sector concentrates (with some exceptions) on measurements
Teresa Mroczek, PhD

Department of Expert Systems and Artificial Intelligence

The University of Information Technology and Management (UITM) in Rzeszow, Poland

E-mail: tmroczek@wsiz.rzeszow.pl

Tomasz Skica, PhD

The Institute for Financial Research and Analyses The University of Information Technology and Management (UITM) in Rzeszow, Poland E-mail: tskica@wsiz.rzeszow.pl

Jacek Rodzinka, $\mathrm{PhD}$

The Institute for Financial Research and Analyses The University of Information Technology and Management (UITM) in Rzeszow, Poland E-mail: jrodzinka@wsiz.rzeszow.pl 
that link public expenditure to GDP.

We're attaching a review of the most well-known research devoted to government size where the authors use government expenditure to express the size of the general government sector. Peden (1991), considering general government spending in the USA for the years 1929-1986, calculated that the optimal size of the U.S. government is at $20 \%$ of GDP. The articles of Grossman (1987 and 1988) are examples of other scientific research that refers to the U.S. economy and that consider relatively long periods demonstrating that optimal size of government fluctuates around $20 \%$ of GDP.

Karras (1997), using the data for 20 European countries and the time period 1950-1990, found that the average optimal size of government for all European countries equals $16 \%(+/-3 \%)$ of GDP. Vedder and Gallaway (1998) proved that the optimal size of federal government in the United States in the period 1947-1997 was $17.45 \%$ of GDP. At the same time the size of state and local government which maximizes the growth rate was equaled in relation to GDP at $11.42 \%$. In fact, the overall optimal government size was $28.87 \%$ of GDP. The results of calculations which were conducted by the authors for five other countries suggest that optimal size of the sector for Canada (1926-1988) was $21.37 \%$ of GDP; for Denmark (18541988 ) it also equaled $26.14 \%$ of GDP; in the case of Italy (1862-1988) its value was $22.23 \%$ of GDP; for Sweden (1881-1988) it was on the level of $19.43 \%$ of GDP, and for Great Britain (1830-1988) it was equal to $20.97 \%$ of GDP.

Chao and Grubel (1998), who conducted calculations for Canada for the time period 1929-1996 (inclusive), determined that optimal size of government spending in Canada was about 27\% of GDP, whereas, Illarionov and Pivovarova (2002), claimed that the optimal size of government which maximizes the economic growth of Russia was in the range from $18 \%$ to $21 \%$ of GDP. Handoussa and Reiffers (2003) conducted analyses on the relationship between government size and economic growth on the example of Tunisia. Based on the data collected for three decades (i.e., from 1968 to 1997), the authors determined that the optimal level of government expenditure in the context of Tunisia was equal to $35 \%$ of GDP.

Interesting conclusions based on Economic and Monetary Union countries (EMU) were given by Buti et al. (2003). The authors proved that the maximum stabilizing size of government is lower for small open economies. Their research results suggest a threshold of about $35 \%$ of GDP in the case of small open economies and somewhat higher (about $40 \%$ of GDP), for large open economies.
Pevcin (2004), analyzed economies of 8 European countries in the period from 1950 to 1996 . He found that optimal size of governments is as follows: Italy (37.09\% GDP), France (42.90\% GDP), Finland $(38.98 \%$ GDP), Sweden (45.96\% GDP), Germany (38.45\% GDP), Ireland (42.28\% GDP), the Netherlands (44.86\% GDP), and Belgium (41.91\% GDP).

Chobanov and Mladenova (2009) conducted research on OECD countries for the period from 1970 to 2007. The authors indicated that the optimal level of combined government expenditure in relation to GDP shouldn't be higher than $25 \%$. To determine the optimal level of government consumption expenditure the authors used data of 81 countries from the World Development Indicators of the World Bank for the period 1961-2005. According to their calculations, the optimal level of government consumption was only $10.4 \%$ of GDP. It is necessary to notice that in most developed countries government consumption as a share of GDP exceeds this threshold. For example, in 2005 government consumption as a share of GDP was $18 \%$ in Australia and Austria, 23\% in Belgium, 25.9\% in Denmark, 22\% in United Kingdom, 16\% in the USA, and $27 \%$ in Sweden. At the same time in Singapore and India government consumption was equal to respectively $10.4 \%$ of GDP, and in Chile $-10.9 \%$.

Davies (2009), moves deliberations on optimal government size from productivity to social welfare, by using the Human Development Index (HDI) as the outcome variable. The author conducted single country studies for 154 countries inside the time frame 1975-2002 taken from the Human Development Report, 2004. According to the results the estimated levels of government consumption and investment expenditures that are associated with maximal growth in per capita real GDP are $8.5 \%$ and $6.2 \%$, respectively. Connection of both these values suggests that the optimal level of government expenditures in the analyzed period was equal to $14.7 \%$ of GDP. In contrast the author suggests that government investment expenditures have a negative impact on the HDI until investment expenditures reach approximately $40 \%$ of GDP.

Mutaşcu and Miloş (2009) divided the EU countries into 'new and old' countries and used the data for the years 1999-2008 (inclusive). They found that the optimal size of government for the new countries equaled $30.42 \%$ of GDP while for the old EU countries $27.46 \%$ of GDP. Gunalp and Dincer (2010) estimated the optimal government size for 20 transition countries based on annual data for the period 1990-2001. The optimal government size was estimated on average to be $17.3 \%$ (+/-3\%) GDP for transition countries.

Abounoorie and Nademi (2010) looked at the 
Iranian economy for the years 1959 - 2006. They analyzed the optimal size of government from the point of view of total government expenditure share in GDP, government consumption expenditure share in GDP, and government investment expenditure share in GDP. They found that in the first case the optimal size of government was about $34.7 \%$ of GDP, in the second $23.6 \%$ of GDP, and for the last case, $8 \%$ of GDP.

Samimi, Nademi and Zobeiri (2010) provided studies based on annual data for Islamic countries for 19802007. The results (expressed with the level of general government final expenditure over GDP), were: Iran $26.4 \%$ of GDP, Pakistan $11.9 \%$ of GDP, Turkey $13.96 \%$ of GDP, Egypt $16.53 \%$ of GDP, Algeria $16.54 \%$ of GDP, Indonesia $7 \%$ of GDP, Oman $26.11 \%$ of GDP, and Jordan 26.09\% of GDP. Forte and Magazzino (2011), analyzing $12 \mathrm{EU}$ economies in the period of $1970-2009$, found that the optimal size of government spending was in the range from $35.39 \%$ GDP for Belgium and 35.52\% for the Netherlands to $43.50 \%$ for UK and $44,47 \%$ GDP for Ireland. Their results for the other analyzed countries look as follow: Austria (38.21\% of GDP), Denmark (38.63\% of GDP), Finland ( $40.38 \%$ of GDP), France (39.49\% of GDP), Germany (41.99\% of GDP), Greece (39.33\% of GDP), Italy (37.68\% of GDP), and Portugal (42.28\% of GDP). Similar conclusions concerning the Italian economy were found by Magazzino (2012), who based his study on the time period from 1960 to 2008 (inclusive).

Herath (2012), based on the data for the years 1959-2009, found that the optimal size of government for Sri Lanka is equal to $27.0 \%$ of GDP. Di Liddo, Magazzino and Porcelli (2013), based on the period of 1997-2009, found that the optimal government size for decentralized government measured by the level of public spending in Italian regions to regional GDP was close to $52 \%$. The authors proved that in the case of lack of decentralization (decentralization index $0.0 \%$ ), the optimal government size was equal to $52.112 \%$. Assuming the existence of decentralization, the authors observed an increase in the optimal size of government from $52.115 \%$, assuming an index of decentralization at the level of $10 \%$ to $52.223 \%$, assuming an index of decentralization at the level of $30 \%$.

Altunc and Aydin (2013) provided research on the optimal size of government for three countries: Turkey, Romania and Bulgaria. The research period involved the years from 1995 to 2011 (inclusive). The authors found that optimal size of government expenditure for Turkey was equal to $25.21 \%$ of GDP, for Romania $20.44 \%$ of GDP, and for Bulgaria $22.45 \%$ of GDP. Hok et al. (2014), organized their research on the basis of 8 ASEAN countries (Brunei, Cambodia,
Indonesia, Malaysia, Philippines, Singapore, Thailand and Vietnam). The time period included the years from 1995 to 2011 (inclusive). The authors found that the optimal size of government (expressed as the level of government expenditures in GDP) for these countries was equal to $28.5 \%$ of GDP.

Alimi (2014), based on annual Nigeria country level data for the period 1970 to 2012, considered two measures of the size of government: share of total expenditures to GDP, and share of recurrent expenditures to GDP. Alimi estimated the optimum share of total government expenditure to GDP at $19.81 \%$ while the share of recurrent expenditures to GDP was $10.98 \%$.

Hajamani and Falahi (2014), analyzed the relationship between the government consumption expenditure share and economic growth in 21 low-income countries and 11 low-middle income countries during 1981-2007. The results showed that the optimal level of government consumption expenditure for low and low-middle income countries was $16.2 \%$ of GDP and $16.9 \%$ of GDP respectively.

Christie (2014), based on the panel data of 136 countries and the time period of 1971-2005, found that the optimal size of government measured with the size of total government expenditures to GDP was 33\% of GDP. Thanh and Hoai (2015) used the panel data for ASEAN countries (Brunei, Cambodia, Indonesia, Laos, Malaysia, the Philippines, Singapore, Thailand and Vietnam), over the period 1980-2011. The empirical results showed that the threshold level of optimal government consumption spending was equal to $25.69 \%$ of GDP. That was the optimal level of government size for supporting sustainable economic growth in ASEAN countries. Two years later, Sriyana (2016) found that optimum level of government spending that maximizes economic growth in Indonesia was $12.552 \%$ of GDP.

Asimakopoulos and Karavias (2016) used the data on 129 countries from the World Development Indicators for the period of 1980-2009. They found that the optimal level of government size (expressed by government consumption expenditure to GDP) that maximizes economic growth was equal to $18.04 \%$ for the full sample of 129 countries, but at the same time $19.12 \%$ for developing countries and $17.96 \%$ for developed countries.

Lyidogan and Turan (2017), examined the relationship between the Turkish government's size and economic growth for the period 1998-2015 (inclusive). According to their results, estimated threshold levels, as a percentage of GDP, were $16.5 \%$ for the government's total expenditures, $12.6 \%$ for consumption expenditures, and 3.9\% for investment expenditures. 
These approaches show that general government size optimalisation has focused mainly on the linkages between government expenditure and the country's GDP. These measures should be seen as a canon in the field of comparative analysis in the area of general government sector size. Due to the universality of these approaches, the authors attempted to determine the optimal (from the point of view of the economy) size of the GGS using the diagnostic inference methodology unparalleled in research devoted to general government sector size optimalisation. Moreover, the authors decided to expand the measures of government size with new variables (or'parameters').

We chose the Bayesian network as a method to analyze data because: encodes dependencies among all variables, can be used to learn causal relationships, understanding about a problem domain and to predict the consequences, has both a causal and probabilistic semantics and additionally Bayesian statistical methods in conjunction with Bayesian networks offer an efficient approach for avoiding the overfitting of data.

\section{DATA AND METHODS}

The research was conducted for EU Member States. Due to the fact that all EU countries were examined, the analysis included both highly developed countries (the so-called old European Union countries) and new member states. The structure of the group of examined countries therefore covered a much more developed Western European countries such as Luxemburg, Belgium and Germany as well as countries of South East Europe including Bulgaria, Greece, Romania and Slovenia. The inclusion of all Member States in the research allowed to construct measures that objectively refer to the EU as a whole, but at the same time, consider the diversity of the Member States that form it. The timeframe covered the years from 2000 to 2013 (inclusive). Sources of data for the purpose of this research were publicly available including: Eurostat, OECD, as well as the World Bank.

The economy was described with the help of thirteen variables: Activity rate (in \%), Balance of the current account (million euro), External balance of goods and services (million euro), FDI - foreign direct investment (million USD), Gross domestic product in current prices per inhabitant (GDP per inhabitant), Harmonized indices of consumer prices (HICPs) (annual average rate of change), Inward FDI flows (million USD), Outward FDI flows (million USD), Real effective exchange rate (index $1999=100$ ), Unemployment rate (in \%), Potential output of total economy (million euro), Gross capital formation (\% GDP), and Gross domestic product in current prices per inhabitant - dynamic (percentage change).

The general government sector was presented through the formation of nine variables that describe it, and they were: Total general government expenditure (euro per inhabitant), the ratio of total taxes to GDP (\% GDP), Public sector employment (number of people), Total general government revenue (euro per inhabitant), Government consolidated gross debt (\% GDP), General government sector output (\% GDP), Gross value added (general government total valueadded) (basic (current) prices), Total general government expenditure (\% GDP), and General government gross fixed capital formation (\% GDP).

Due to the fact that the variables had a constant character, they have been subjected to a discretization process. The values of each variable have been divided into four intervals. An interval criterion was an equal number of occurrences in every interval, so there were exactly the same number of countries belonging to the $\mathrm{EU}$ in every single interval. Every variable and every interval were studied for positive impact on the variables that describe a condition of the economy. In these analyses Bayesian Networks (BNs) were used.

The BNs were generated considering each year separately (i.e. the first network was generated on the basis of data from the year 2000, the second from the year 2001, etc.). Due to the fact that the Bayesian network determines a joint probability distribution it can be used for inference. The diagnostic inferences were conducted to determine in which values of the parameters describing the size of the general government sector are the improvement of indicators describing the economy of the studied EU countries. Diagnostic inference was held to be optimal from the point of view of the economy of the size of the general government sector. To set the variables of the economy (effects) a probability distribution of the indicators with GGS (causes) was observed. As a result of the logical output the observed attributes were valued, which reached a level of probability greater or equal to 0.7 .

Afterwards, by interpreting the results of the diagnostic inference variables of GGS variables those with the biggest and as a consequence the widest impact on the economy sector were pointed out. By optimizing impact, the level of the studied variables was precisely determined. 


\section{DIAGNOSTIC INFERENCE}

A Bayesian Network (BN) is a pair (DAG, CPD) where the nodes and arcs form a directed, acyclic graph (DAG) and the conditional probability distribution (CPD) of a node (a random variable) is defined for every possible outcome of the preceding causal node(s) (see: Pearl 1988). If there exists a causal probabilistic dependence between two random variables in the DAG, the corresponding two nodes are connected by a directed edge while the directed edge from a node $A$ to a node $B$ indicates that the random variable $A$ causes the random variable $B$. Each node is annotated with a conditional probability distribution (CPD), that represents $p(B \mid A)$, where $A$ denotes the preceding of $B$ in DAG.

Due to the fact that the $\mathrm{BN}$ determines a joint probability distribution it can be used for inference. The most common inference methods are predictive inference (from causes to effects) - from new information about causes to new beliefs about effects, according to the directions of the network arcs and diagnostic inference - (from effects to causes), effects are known to look for causes, in the opposite direction to the network arcs (Hagmayer et al. 2007; Pearl 2009; Korb et al. 2004).

To demonstrate the diagnostic inference let's assume now that inflation has fallen and observe the causes. In other words, we observe I = yes with probability 1 and we wonder how the probability distribution of supply factors SFs and demand factors DFs changes, given the observed effect. Based on the Bayes formula we observe:

$$
\begin{gathered}
P(S F s=\text { yes } \mid I=\text { yes })= \\
\sum_{D F s} \frac{P(S F s=y e s) P(D F s) P(I=\text { yes } \mid S F s=\text { yes, } D F s)}{P(I=y e s)}=0.4 \\
P(D F s=y e s \mid I=y e s)= \\
\sum_{S F S} \frac{P(S F s) P(D F s=y e s) P(I=y e s \mid S F s, D F s=y e s)}{P(I=y e s)}=0.73
\end{gathered}
$$

The graphical interpretation with posterior probability distribution - after observing inflation decrease - is presented in Figure 1.

How to interpret diagnostic inference results? The effect of some event has occurred - in our case inflation has fallen. So, we are looking for what are the probable causes of the fall in inflation. For this purpose, we observe variables that have an impact on the inflation fall (i.e. variables connected directly and/ or indirectly with the inflation fall). The observation of variables means observing changes in probability (equations 4 and 5), which took place as a result of an inflation fall. The higher the probability value, the more likely the cause is. In our case, demand factors DFs are the more probable cause of the inflation fall.

BNs have been applied in a wide range of areas in health services research: health economic evaluation, health quality measurement, health outcomes monitoring, cost-effectiveness analysis but also, in epidemiology, clinical research, medical decision making,

Figure 1. DAG representing two independent potential causes of inflation decrease after observing the effect

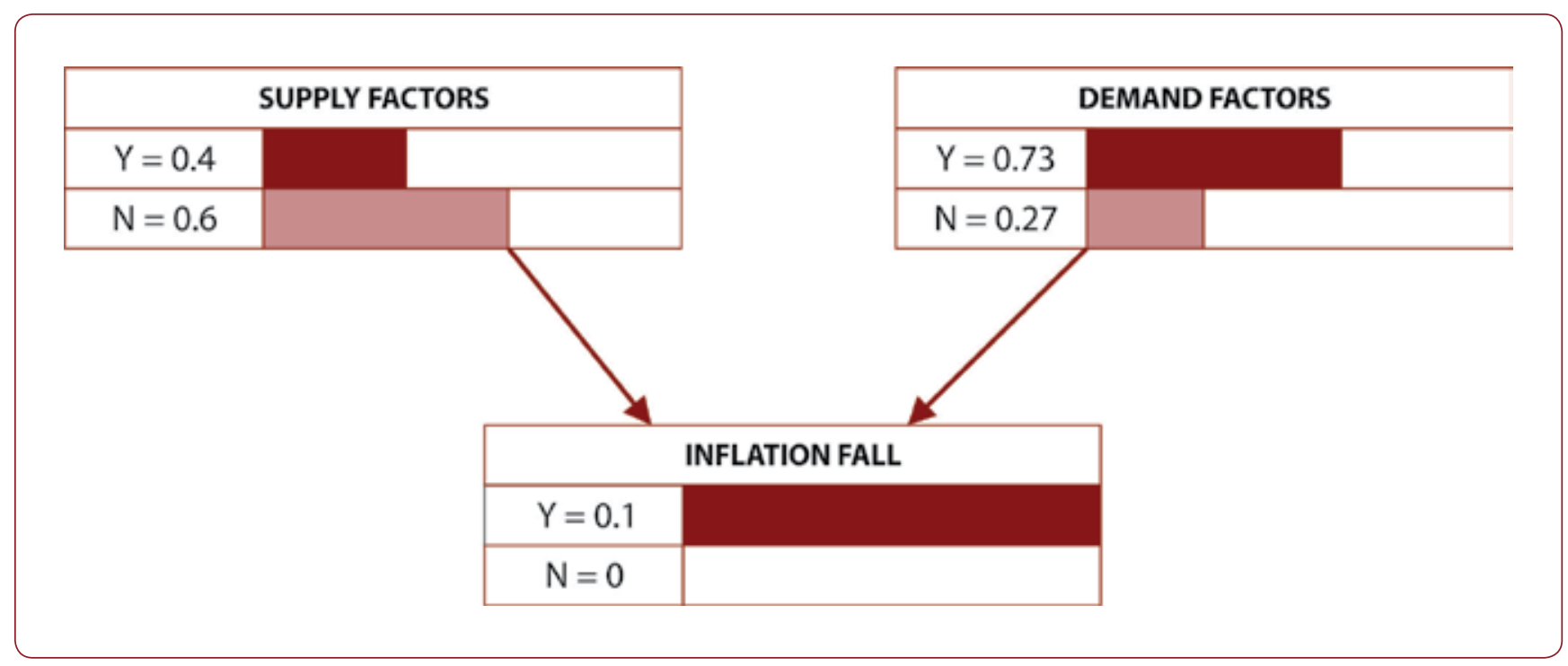

Source: authors 
public health or economics (recently: Quang 2010; Gadewadikar et al. 2010; Harding 2011; Cobb 2011; Sesen et al. 2013; Skica et al. 2015a).

\section{OPTIMIZATION OF THE GGS SIZE}

In order to set the values of parameters describing the size of the GGS at which there is an improvement of indicators describing the economies of EU countries, a diagnostic inference was used which was conducted for an optimal from a perspective of economy size of the general government sector (GGS). On the basis of the observable probability distributions the values of parameters describing the size of the general government sector were set, which affected the improvement of indicators describing the economy of the studied countries (see: Table 1). This means that the values of these parameters outside these intervals result in the worsening of indicators describing the economies of the studied EU countries.

The strongest influence on variables attributable to the economy was noted for the variable marked number 1 (i.e. Total general government expenditure (euro per inhabitant), with a probability of 0.7 it influenced all variables describing an economy. This variable has the strongest impact in the interval of values between 12076 and 21463. Among this interval of values, it influences seven economic variables, but when the interval of values is between 699 and 5854 it impacts six variables describing an economy.

Three variables describing the size of the GGS, i.e.: The ratio of total taxes to GDP (\% GDP), Public sector employment (number of people), Total general government revenue (euro per inhabitant) impact 12 out of 13 variables describing the economy. They differ from each other as each influences a different variable describing the economy. The ratio of total taxes to GDP (\% GDP) does not influence significantly Gross domestic product in current prices per inhabitant (GDP per inhabitant), however Public sector employment (number of people) does not have a substantial impact on balance of the current account (million euro), but Total general government revenue (euro per inhabitant) does not affect strongly external balance of goods and services (million euro).

In order for the sector variable Ratio of total taxes to GDP (\% GDP) to have the strongest positive impact on economic variables it should be present in interval of values from 27.4 to 34.5.

Public sector employment (number of people) influences positively and in the strongest way 11 variables describing the economy when it is set in the interval of values from 1015.7 to 3053.8 . In case of the variable FDI - foreign direct investment (million USD) the strongest positive impact was assessed for the interval of values from 32.5 to 440.0 .

Other variables from the GGS characterize with minor impact on the economy:

1) Government consolidated gross debt (\% GDP) and General government sector output (\% GDP) affect only economic variables: Gross domestic product in current prices per inhabitant (GDP per inhabitant) as well as Gross capital formation (\% GDP), however the first affects in the strongest manner, when its value is in the interval from 3.7 to 31.2 , the second affects in the strongest manner when its value is in the interval from 12.0 to 16.8 for the variable Gross domestic product in current prices per inhabitant (GDP per inhabitant), in turn for the variable Gross capital formation (\% GDP) it is the most significant for values from the interval from 16.8 to 20.2;

2) Gross value added (general government total value-added) (basic (current) prices) in the interval from 11.8 to 14.3 affects the strongest variables: Harmonized indices of consumer prices (HICPs) (annual average rate of change), Unemployment rate (in \%) and Gross capital formation (\% GDP). On the other hand, in the interval from 8.6 to 11.8 it affects Gross domestic product in current prices per inhabitant (GDP per inhabitant);

3) Total general government expenditure (\% GDP) influences positively two variables on the economy side. The first, Gross domestic product in current prices per inhabitant (GDP per inhabitant), is where it acts the strongest when its values are in the interval from 40.3 to 46.7 and for the variable Gross capital formation (\% GDP) it acts the strongest when its values are in the interval from 31.1 to 40.3 ;

4) The last in order variable describing size of the GGS is General government gross fixed capital formation (\% GDP). It influences positively only one variable on the side of economy and that variable is Harmonized indices of consumer prices (HICPs) (annual average rate of change). It has the strongest impact on it in the interval of values from 3.44 to 4.45 .

Analyzing data from Table 2 it is worth pointing out one more extremely important fact. Variables described in the table by numbers from 1 to 4 influence substantially all or most of the variables describing the economy. Affecting their level and putting their values in the table intervals it is possible to impact in the strongest manner the economies of the studied EU countries. 


\begin{tabular}{|c|c|c|c|c|c|c|c|c|c|}
\hline 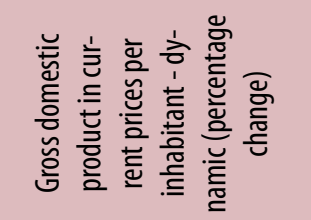 & 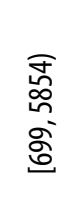 & 堊 & 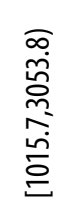 & 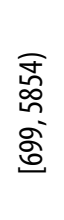 & & & & & \\
\hline 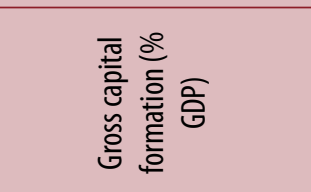 & 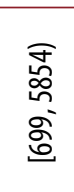 & 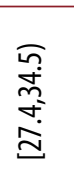 & 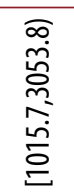 & 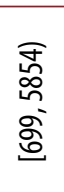 & $\underset{\substack{m \\
m}}{\stackrel{m}{m}}$ & 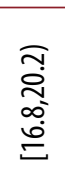 & 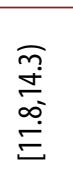 & 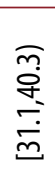 & \\
\hline 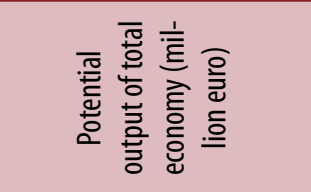 & 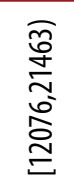 & 堊 & 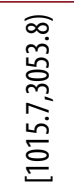 & 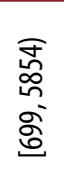 & & & & & \\
\hline 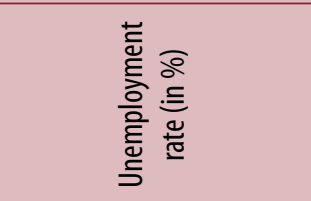 & 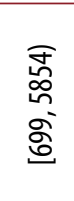 & 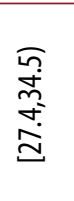 & 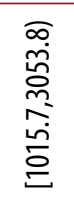 & 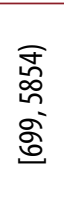 & & & 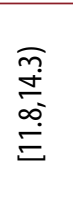 & & \\
\hline 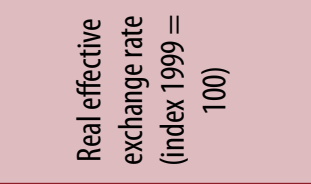 & 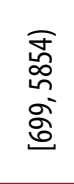 & 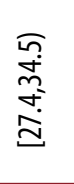 & 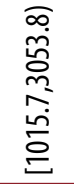 & 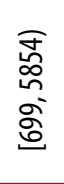 & & & & & \\
\hline 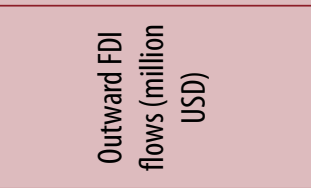 & 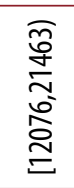 & 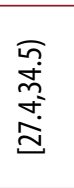 & 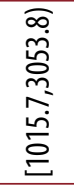 & 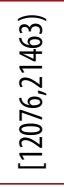 & & & & & \\
\hline 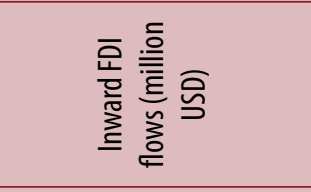 & 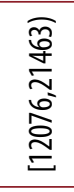 & 垈 & 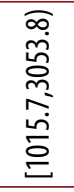 & 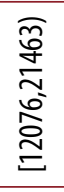 & & & & & \\
\hline 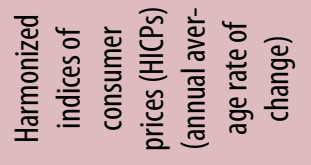 & 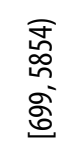 & 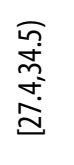 & 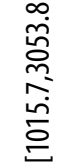 & 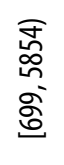 & & & 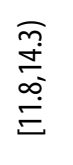 & & 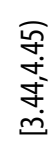 \\
\hline 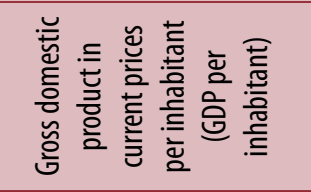 & 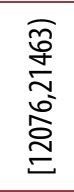 & & 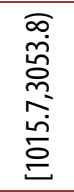 & 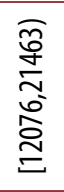 & $\underset{\substack{m \\
m}}{\stackrel{\bar{m}}{m}}$ & 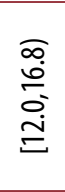 & 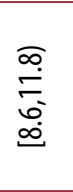 & 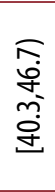 & \\
\hline 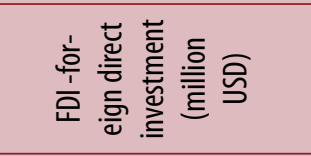 & $\begin{array}{l}\text { F } \\
\text { 岁 } \\
\text { ò } \\
\text { o. }\end{array}$ & 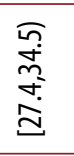 & 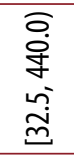 & 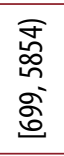 & & & & & \\
\hline 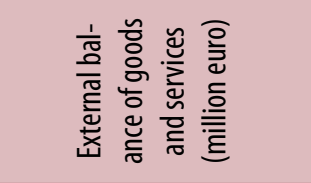 & 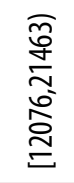 & 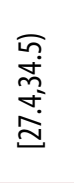 & 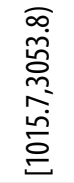 & & & & & & \\
\hline 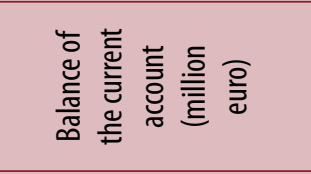 & 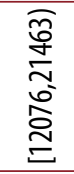 & 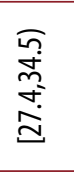 & & 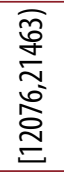 & & & & & \\
\hline 莺 & 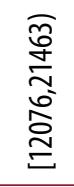 & 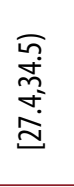 & 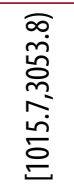 & 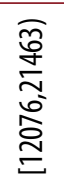 & & & & & \\
\hline & - & $\sim$ & $m$ & $\sigma$ & in & 0 & $n$ & $\infty$ & $a$ \\
\hline
\end{tabular}

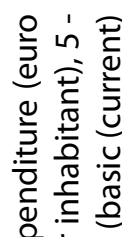

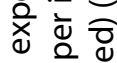

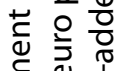
(5) ㅇํㅇ क을 v बे है है 으 ว

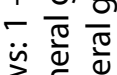
응 ज্

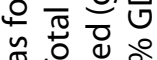
这宁

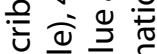
웡 응 o

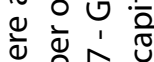

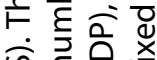
ডु

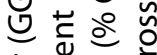
흘 品 응 은 烍 हे ఫे गे

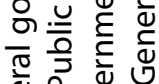
वे ธำ

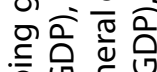
을 웡응 造高

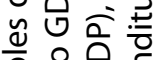
응 웡

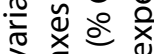

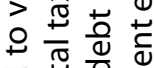
읃 훙 응 눙응

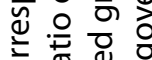
훙 o 눙 ह

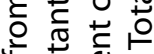

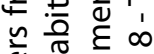
है

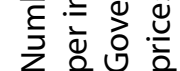


Table 2. Optimal value of variables describing size of the GGS from a perspective of positive affect on maximum number of economic variables

\begin{tabular}{|c|l|c|}
\hline No. & Name of variable describing size of the GGS & $\begin{array}{c}\text { Desired value of variable describing size of } \\
\text { the GGS }\end{array}$ \\
\hline 1. & Total general government expenditure (euro per inhabitant) & from 699 to 5854 or from 12067 to 21463 \\
\hline 2. & The ratio of total taxes to GDP (\% GDP) 27.4 to 34.5 \\
\hline 3. & Public sector employment (number of people) & from 3.7 to 31.3 \\
\hline 4. & Total general government revenue (euro per inhabitant) & from 12.0 to 20.2 \\
\hline 5. & Government consolidated gross debt (\% GDP) & from 8.6 to 14.3 \\
\hline 6. & General government sector output (\% GDP) 699 to 5854 or from 12067 to 21463 \\
\hline 7. & $\begin{array}{l}\text { Gross value added (general government total value-added) } \\
\text { (basic (current) prices) }\end{array}$ & from 31.1 to 46.7 \\
\hline 8. & Total general government expenditure (\% GDP) & from 3.44 to 4.45 \\
\hline 9. & General government gross fixed capital formation (\% GDP) & from 1015.7 to 3053.8 \\
\hline
\end{tabular}

Source: authors

However, paradoxically from a perspective of economic policy, more valuable could be the results describing sector variables located on numbers 5 to 9 , because their application will be affecting only chosen economic indicators. People responsible for shaping economic policy in a country, might, because of changing particular values on the side of variables describing size of GGS, positively influence changes of values only for selected indicators on the economy side.

\section{OPTIMIZATION OF SIZE OF THE GGS}

From a perspective of the objective set by the authors in this elaboration it is worth attempting to show optimal size of the GGS that in the strongest manner would positively affect the economy of EU countries. In Table 3 there are intervals of values presented, in which variables describing size of the GGS should be featured from a perspective of positive impact on the biggest number of variables on the economy side. In order to fulfill that assumption variables on the side of the GGS could have values from a maximum of 2 (out of four) intervals of values, into which they were divided in the analysis.

Intervals of values presented in Table 3 correspond to positive impact of variables describing size of the GGS on as many as possible variables describing economies. Taking this into account, in the next step there was an attempt to establish optimal size of variables describing GGS from the perspective of the most favorable influence on the maximum number of variables describing the economy.

While creating Table 1 there was an objective to establish only one, narrow interval of values for each variable on the side of the GGS in order to indicate most accurately intervals of values where these variables should be present. A criterion of choice for this one interval for variables representing sizes of the GGS was the fact that in this interval a variable would have a positive impact on the greatest number of variables on the economy side. In the case of two variables i.e.: General government sector output (\% GDP) as well as Total general government expenditure (\% GDP) using that criterion it was impossible to indicate only one interval, so two intervals were indicated, because in each of them they influence to the highest possible extent exactly one variable; as a result, it is not possible to indicate which one is the most important.

As an example, the variable General government sector output (\% GDP) in the interval from 12.0 to 16.8 affects positively the variable Gross domestic product in current prices per inhabitant (GDP per inhabitant), while in the interval from 16.8 to 20.2 it affects positively the variable Gross capital formation (\% GDP). Thus, indication of which interval of this variable is better for the economy is not possible, as in each of them it affects positively only one, however different, variable. It is a similar situation with the variable Total general government expenditure (\% GDP), that in the interval from 31.1 to 40.3 it impacts positively only Gross capital formation (\% GDP), while in the interval of values from 40.3 to 46.7 it influences positively Gross domestic product in current prices per inhabitant (GDP per inhabitant).

Table 1 presents optimal size of the general government sector from the perspective of its positive impact on the economy. Every economic variable is influenced positively at least by one variable on the 
Table 3. Optimal values of variables describing size of the GGS from the perspective of the most favorable influence on the maximum number of variables describing the economy

\begin{tabular}{|c|c|c|}
\hline No. & Variable describing size of the GGS & $\begin{array}{l}\text { Desired value of variable describing } \\
\text { size of the GGS }\end{array}$ \\
\hline 1. & Total general government expenditure (euro per inhabitant) & from 12067 to 21463 \\
\hline 2. & The ratio of total taxes to GDP (\% GDP) & from 27.4 to 34.5 \\
\hline 3. & Public sector employment (number of people) & from 1015.7 to 3053.8 \\
\hline 4. & Total general government expenditure (euro per inhabitant) & from 699 to 5854 \\
\hline 5. & Government consolidated gross debt (\% GDP) & from 3.7 to 31.3 \\
\hline 6. & General government sector output (\% GDP) & from 12.0 to 16.8 or from 16.8 to 20.2 \\
\hline 7. & $\begin{array}{l}\text { Gross value added (general government total value-added) } \\
\text { (basic (current) prices) }\end{array}$ & from 11.8 to 14.3 \\
\hline 8. & Total general government expenditure (\% GDP) & from 31.1 to 40.3 or from 40.3 to 46.7 \\
\hline 9. & General government gross fixed capital formation (\% GDP) & from 3.44 to 4.45 \\
\hline
\end{tabular}

Source: authors

side of the GGS, while it happens twice that this positive impact is coming from even from five variables describing size of the GGS. It means that GGS holistically affects an economy, what is important from the perspective of economic policy is that there are no variables on the side of the economy that is not influenced by at least one variable on the side of the GGS. It demonstrates substantial possibilities for economic stimulation by proper definition of size of the GGS.

Data included in the research let us accurately construct policy in a scope of shaping size of the GGS that in the most optimal way would influence the economy using tools that can be called 'universal', which impact vast number of economic variables, to those that affect only single economic variables. In the article ready solutions serving the improvement of the economic situation of the studied countries could be found.

\section{CLOSING REMARKS}

The analysis allowed us to determine in which intervals values of variables describing size of the GGS affect positively the economy. It is established that the most important for the economy are the variables: Total general government expenditure (euro per inhabitant), Ratio of total taxes to GDP (\% GDP), Public sector employment (number of people), and Total general government expenditure (euro per inhabitant) - they influence positively all, or most of the variables on the economy side. In the case of other variables describing size of the GGS from one to five variables were indicated on the side of the economy sector which they impacted.
The greatest achievement of the authors was however indication of specified intervals of values, where particular variables of the GGS affect positively variables from the economy sector. In Table 3 optimal intervals of values of the variables on the side of the GGS were presented. Those intervals are broad, but chosen in such way that they impact the greatest number of economic variables. On the other hand, in Table 1 those intervals were narrowed in order to determine the maximum precise optimum level of the studied variables.

The results on optimizing size of the GGS might be an important source of information for the purpose of economic policy planning for each of the studied economies especially those, represents South East Europe countries. The results of the estimates carried out provide guidance for developed Western European countries. Despite the level of development, they have achieved, in many cases they struggle with the problems of economic development stabilization, as well as problems related to public finance management. Provided estimates allow these countries to adjust the size of the public finance sector to the economic condition of these countries. This solution will contribute to economic stability. On the other hand, in the case of developing countries including SEE countries, optimization of the GGS size will allow overcoming development barriers ensuring adjustment of the sector size to the current state and economic condition of these countries. Thus, the modification of the size of GGS should be treated as one of the factors that will support the dynamics of the development processes of these countries and contribute to leveling the development disparities separating the more developed (albeit not free from problems) countries 
of the Western Europe and SEE countries.

Findings made during the research are an expression of an alternative and innovative approach not only to studying impact of size of the general government sector on single economic parameters, but also on the economy expressed through the prism of all parameters within the research - together. An essential value added that is a result of this study is the capture of differentiation of scale of the influence of different parameters of the GGS as well as their individual correlation with economic variables. As a result of these analyses, the authors have elaborated a kind of policy mix effectively linking size of the sector with expectations towards the economic performance of a country determined by sector parameters.

This article is the first step for the development of analyses devoted to the optimization of general government sector size and its impact on the economy. The conclusions suggest that the next step in explanation of the studied issue should be extending the research by analyzing the relationship between general government sector size and economic growth. The data collected determine the optimal general government sector size in static terms. It limits the presented work and the results contained in it. From the viewpoint of the topic, it becomes extremely important to determine the impact of the size of the general government sector on the dynamics of economic growth. The approach based on the data collected will examine how the optimal size of the general government sector (determined for the studied time period) has a positive effect on the economic dynamics of the surveyed countries. The results obtained will allow to determine whether the general government sector size optimizes the dynamics of economic growth, with regard to the time and place circumstances.

\section{REFERENCES}

Abounoori, E., Nademi, Y. 2010. Government Size Threshold and Economic Growth in Iran. International Journal of Business and Development Studies 2 (1): 95-108.

Alimi, R. S. 2014. Does Optimal Government Size Exists for Developing Economies? The Case of Nigeria. MPRA Paper No. 56073. https://mpra.ub.uni-muenchen.de/56073/1/ MPRA paper 56073.pdf (accessed June 16, 2019).

Altunc, O. F., Aydın, C. 2013. The relationship between optimal size of government and economic growth: Empirical evidence from Turkey, Romania and Bulgaria. ProcediaSocial and Behavioral Sciences (92): 66-75.

Asimakopoulos, S., Karavias, Y. 2016. The impact of government size on economic growth: A threshold analysis. Economics Letters (139): 65-68.
Barro, R. J. 1990. Government Spending in a Simple Model of Endogenous Growth. Journal of Political Economy 98(5): 103-125.

Chao, J. C., Grubel, H. 1998. Optimal levels of spending and taxation in Canada. How to use the fiscal surplus: What is the optimal size of government: $53-68$ https://www.fraserinstitute.org/sites/default/files/ HowtoUseFiscalSurplusOptimalLevels.pdf (accessed June 17, 2019).

Chobanov, D., Mladenova, A. 2009. What is the optimum size of government. Institute for Market Economics, Bulgaria: 1-47 http://citeseerx.ist.psu.edu/viewdoc/download?doi=1 0.1.1.694.7767\&rep $=$ rep1\&type $=$ pdf (accessed June 18, 2019).

Cobb, B. 2011. Graphical models for economic profit maximization. INFORMS Transactions on Education 11 (2): 43-56.

Di Liddo, G., Magazzino, C., Porcelli, F. 2013. Decentralization, growth and optimal government size in the Italian regional framework. A BARS curve approach. CREI Working Paper No 1: 1-47 http://host.uniroma3.it/centri/crei/ pubblicazioni/workingpapers2015/CREI 01_2015.pdf (accessed July 15, 2019).

Forte, F., Magazzino, C. 2011. Optimal size government and economic growth in EU countries. Economia Politica 28 (3): 295-322.

Gadewadikar, J., Kuljaca, O., Agyepong, K., Sarigul, E., Zheng, Y., Zhang, P. 2010. Exploring Bayesian networks for medical decision support in breast cancer detection. African Journal of Mathematics and Computer Science Research 3 (10): 225-231.

Grossman, P. J. 1987. The optimal size of government. Public Choice 53 (2): 131-147.

Grossman, P. J. 1988. Growth in government and economic growth: The Australian experience. Australian Economic Papers 27 (50): 33-43.

Gunalp, B., Dincer, O. C. 2010. The optimal Government Size in Transition Countries. Progress in Economics Research Vol. 15: 153-169.

Hagmayer, Y., Sloman, S. A., Lagnado, D. A., Waldmann, M. R. 2007. Causal reasoning through intervention. In Causal learning: Psychology, philosophy, and computation, edited by A. Gopnik, L. Schulz, 86-100. Oxford-New York: Oxford University Press.

Hajamani, M., Falahi, M. A. 2014. The Nonlinear Impact of Government Consumption Expenditure on Growth: Evidence from Low and Low-Middle Income Countries. Cogent Economics \& Finance (2): 1-15.

Handoussa, H., Reiffers, J. L. 2003. Femise report on the EuroMediterranean partnership: analysis and proposals of the Euro-Mediterranean Forum of Economic Institutes. Report presented at the Steering Committee of FEMISE, Marseilles, France, September. http://www.femise.net/ PDF/Femise A2003gb.pdf (accessed July 19, 2019). 
Harding, N. J. 2011. Application of Bayesian networks to problems within obesity epidemiology (Doctoral dissertation, University of Manchester). https://www.escholar. manchester.ac.uk/api/datastream?publicationPid=ukac-man-scw:122878\&datastreamld=FULL-TEXT.PDF (accessed July 21, 2019).

Herath, S. 2012. Size of Government and Economic Growth: A Nonlinear Analysis. Economic Annals 57 (194): 7-30.

Hok, L., Jariyapan, P., Buddhawongsa, P., Tansuchat, R. 2014. Optimal Size of Government Spending: Empirical Evidence from Eight Countries in Southeast Asia. The Empirical Econometrics and Quantitative Economics Letters 3 (4): 31-44.

Illarionov, A., Pivovarova, N. 2002. The size of government and economic growth. Voprosy Economiki No 9: 18-45.

Karras, G. 1997. On the optimal government size in Europe: theory and empirical evidence. The Manchester School 65 (3): 280-294.

Korb, K. B., Hope, L. R., Nicholson, A. E., Axnick, K. 2004. Varieties of causal intervention. In PRICAI 2004: Trends in Artificial Intelligence. PRICAI 2004. Lecture Notes in Computer Science, edited by C. W. Zhang, H. Guesgen, W. K. Yeap Vol 3157: 322-331. Springer, Berlin, Heidelberg.

Lyidogan, P. V., Turan, T. 2017. Government Size and Economic Growth in Turkey: A Threshold Regression Analysis. Prague Economic Papers (2): 142-154.

Magazzino, C. 2012. Wagner versus Keynes: Public spending and national income in Italy. Journal of Policy Modeling 34 (6): 890-905.

Mutaşcu, M., Milo, M. 2009. Optimal Size of Government Spending. The Case of European Union Member States. Annales Universitatis Apulensis Series Oeconomica 11 (1): 447-456.

Pearl, J. 1988. Probabilistic Inference in Intelligent Systems: Networks of Plausible Inference. San Mateo, CA: Morgan Kaufmann Publishers.

Pearl, J. 2009. Causality: Models, Reasoning and Inference. 2nd edition. Cambridge, UK: Cambridge University Press.
Peden, E. A. 1991. Productivity in the United States and Its Relationship to Government Activity: An Analysis of 57 Years, 1929-1986. Public Choice 69 (1): 153-173.

Pevcin, P. 2004. Does optimal size of government spending exist? University of Ljubljana 10 (1): 101-135.

Quang, A. L. 2010. New Approaches Using Probabilistic Graphical Models in Health Economics and Outcomes Research. University of Southern California, CA: ProQuest Dissertations Publishing.

Samimi, A., Nademi, Y., Zobeiri, H. 2010. Government size \& Economic Growth: A threshold regression approach in selected Islamic countries. Australian Journal of Basic and Applied Sciences 4 (8): 2247-2249.

Sesen, M. B., Nicholson, A. E., Banares-Alcantara, R., Kadir, T., Brady, M. 2013. Bayesian networks for clinical decision support in lung cancer care. PloS one 8 (12), e82349 https://doi.org/10.1371/journal.pone.0082349

Skica, T., Rodzinka, J., Mroczek, T. 2015a. Data mining approach to determine the relationships between the economy and the general government sector size. The Financial Internet Quarterly e-Finanse Vol. 11, No (3): $1-21$.

Skica, T., Rodzinka, J., Fryc, B. 2015b. Application of lem2 algorithm in identification of relationships between the size of general government sector and the economy. Hyperion International Journal of Econophysics \& New Economy 8 (2): 361-401.

Thanh, S. D., Hoai, B. T. M. 2015. The Threshold of Government Size and Economic Growth for ASEAN Countries: An analysis of the smooth transition regression model. Southeast Asian Journal of Economics 3 (1): 103-124.

Vedder, R., Gallaway, L. E. 1998. Government size and economic growth. The Joint Economic Committee. https:// www.jec.senate.gov/public/ cache/files/da82f715a9d3-4625-8cf2-264b11153962/government-size-andeconomic-growth.pdf (accessed July 20, 2019). 